\title{
JUSTICIABILITY OF ECONOMIC, SOCIAL AND CULTURAL RIGHTS IN INTERNATIONAL LAW AND ITS FUTURE IMPLEMENTATION IN INDONESIA
}

\author{
Irawati Handayani \\ Faculty of Law, University of Padjadjaran, Bandung, Indonesia \\ E-mail: irawati@unpad.ac.id
}

\begin{abstract}
Economic, social, and cultural rights are categorized as second generation of rights in the concept of international human rights law. Due to its distinction with first generation right, which is civil and political right, it leads to the differentiation of justiciability of second-generation rights. It's quite often that the fulfillment of economic, social, and cultural rights is postponed, while on the contrary civil and political rights have to be accomplished immediately. The query of justiciability of economic, social, and cultural rights rottenly links with the responsibility of state parties on implementing the rights enumerated in ICCPR or ICESCR. Referring to Article 2 of ICESCR, the implementation of rights stated in ICESCR could be in progressive manner and usually this article is used as an excuse to delay its fullfiment. This article will elaborate further the implementation of protection of economic, social, and cultural rights in another country particularly in South Africa and compare it with the practice of Indonesia in order to achieve an ideal form of justiciability of this second generation of rights.
\end{abstract}

Keywords: justiciability, economic social and cultural rights, second generation rights, right to education, right to housing

\section{A. INTRODUCTION}

The Universal Declaration on Human Rights (UDHR) 1948 is the main pillar of basic human rights entitled to any human beings which has been recognized by all nations in the world. In general, this instrument contains rights categorized as civil and political rights (CP rights) and economic, social, and cultural rights (ESC rights). At first there is no strict line between these two rights, which can also be grouped to "first-generation human rights" and "second-generation human rights". The fundamental idea on human right is its "universal, indivisible, interdependent, and interrelated" nature. Subsequent to the development of both the International Covenant on Civil and Political Rights 1966 (ICCPR) and the International Covenant on Economic, Social, and Cultural Rights 1966 (ICESCR), it was decided that the $\mathrm{CP}$ rights fall under the "first-generation human rights" whereas the ESC rights fall under the "second-generation human rights" due to the perspective during the

\begin{tabular}{ll|l}
\hline Yustisia Vol. 7 Number 3 (Sept.-Dec. 2018) & Justiciability Of Economic, Social ... & 451
\end{tabular}

C2018; This is an Open Acces Research distributed under the term of the Creative Commons Attribution Licencee (https://Creativecommons.org/licences/by/4.0), which permits unrestricted use, distribution, and reproduction in any medium, provided the original works is properly cited. 
drafting process of both covenants which found that both generation of rights have dissimilarity in their nature, origin, and interest. (Matthew Craven, 1998: 7)

The categorization of rights soon invokes questions on the justiciability or the judicial procedure to claim the fulfillment of the rights; can the justiciability for ESC rights be fulfilled just like the $\mathrm{CP}$ rights? It is often seen when a torture victim seeks their compensation or remedy by filing a lawsuit to the government and stating that their freedom from torture had been violated, on the other hand, what about someone who has been denied their right to education; can they file a lawsuit to the government to fulfill that right and will the government ever give them any compensation?

One of the causes to this issue is when a misunderstanding arises on how the ESC rights and $\mathrm{CP}$ rights are being viewed. The general overview perceives the acute differences between those rights as how ECS rights are seen as positive rights, whereas $\mathrm{CP}$ rights are seen as negative rights (Ifdal Kasim and Johanes da Masenus Arus, 2001 : xiii). ESC rights as positive rights can be concluded from how active the State has to act upon realizing the rights. When on the other side, the State has to decrease its participation in the fulfillment of $\mathrm{CP}$ rights (negative rights) and act passively instead. This understanding can therefore be "misleading" for incurring that the ESC rights are not "real" (not really rights) and are only seen as a political statement. (Ifdal Kasim and Johanes da Masenus Arus, 2001 : xiii)

In relation to the state responsibility for both categories, the understanding seems to be that a State has an obligation of conduct to fulfill the CP rights whereas the State only has an obligation of result on how the ESC rights are being fulfilled. As a matter of fact, this understanding is quite inaccurate since both obligations should be implemented by the State on fulfilling ESC rights. For example, a State is responsible to ensure foodstuff necessity for its nationals by taking the right steps and policies to make sure that the foodstuff necessity is attained for (obligation of result), and at the same time the State also has to assure that the people does not lose their freedom to choose an occupation (obligation of conduct). Thus, it can be seen that both obligations should be applied to ESC rights.

Indonesia, as one of the States to ratify ICESCR in 2005, although a bit late compared to other 156 States (http://indicators.ohchr.org/), has an obligation and has been bound to implement all the provisions under ICESCR aside from any "reservations" it has taken. Indonesia ratifies ICESCR through Law Number 11 of 2005 on the Ratification of ICESCR, and as State Party to the covenant, Indonesia has an obligation to fulfill the rights of its nationals, such as right to education, right to occupation, right to adequate food, right to health, and other rights that fall under the scope of ESC rights.

After the ratification of ICESCR, the question on whether the people should just wait for the State to fulfill their ESC rights arises. Evidently, this is not the case.

452 Yustisia Vol. 7 Number 3 (Sept.-Dec. 2018) $\quad$ Justiciability Of Economic, Social ... 
State has the obligation to provide any means available to ensure the realization of ESC rights and as such, there is uncertainty in the justiciability of these rights mainly due to the massive resources the State has to provide (Ida Elisabeth Koch, 2006 : 405-430) for its nationals.

In Indonesia, for example, one of the fundamental human rights for its people is the right to education. The basic principle to this right is that every child is entitled for compulsory and free education. It is then a problem when parents are too poor to provide education for their children, and can they apply for any judicial procedure to resolve this problem? Can parents file a lawsuit to the court and ask the judge to examine and decide on a judgment regarding whether the State has neglected its obligation to facilitate their children education? Another fundamental human right is the right to housing, can the people whose right to housing have been denied under the governmental notion on managing the city apply for their right to the court?

As a right, the fulfillment of ESC rights is entitled to anyone and to any community; and the most important aspect is that those rights are not only embodied in the constitution without any implementation, because the highest priority is to evaluate how to ensure the fulfillment of those rights through judicial procedures.

\section{B. PROBLEM STATEMENT}

This research aims to, firstly, elaborate the practice of states on the justiciability of economic, social and cultural rights that shows on how states respond to the fulfillment of that rights. Secondly, it aims to analyze the prospect of justiciability of economic, social and cultural rights in Indonesia.

\section{RESEARCH METHODS}

This research will apply normative approach by analyzing relevant international conventions law and other documents, as well as the results of research, assessment and other references related to human rights, particularly its justiciability. This research is also utilizing a comparative study to examine practices with respect to several human rights norms that categorized under the economic, social and cultural rights that implemented in other countries.

\section{DISCUSSION AND RESEARCH RESULTS}

\section{General Overview on Human Rights}

It is the notion of common knowledge and hardly arguable that human rights has the nature of universality and all human rights as well as the basic freedoms have the characteristic of "indivisible, interrelated, interdependent, and of equal 
importance to human dignity" (Vienna Declaration and Programme of Action, 1993 : para. 5). This statement is further elaborated in the Preamble of UDHR as established by the General Assembly of the United Nations (UN):

"The people of the United Nations have in the Charter reaffirmed their faith in fundamental human rights, in the dignity and worth of the human person, and in the equal rights of men and women, and have determined to promote social progress and better standard of life in larger freedom."

Although the conception of human rights can also be found on several religions and political systems throughout the development of human civilization, the international regime on human rights in the beginning of $21_{\text {st }}$ century is derived from religious values, morality, philosophies, and political conceptions developed in Europe (Ellie Palmer, 2007 :12). The evolution process on human rights in the western countries could be perceived as a complex process, mostly because of the ever-growing political systems and religious values, however the origin of human rights is established in the early $17_{\text {th }}$ century in England, France, and in the United States of America. (the American Declaration of Independence 1776 and French Declaration of the Rights of Man and the Citizen 1789)

Based on the history, human rights were first seen as "natural rights" in the likes of the right to live, the right of personal freedom, the right of property, and the right of religion. Subsequently, the ESC rights began to be acknowledged in the early $20_{\text {th }}$ century due to the growing movement of the labor workers during that time. This acknowledgment for ESC rights showed an obligation from the State to provide any available resources; such as education and adequate livelihood. Consequently, the comprehension on the importance of other rights aside from CP rights for the integrity and dignity of human has become apparent, as stated in the Preamble of UDHR:

"The advent of a world in which human beings shall enjoy freedom

of speech and belief and freedom from fear and want ... [as] ... the

highest aspiration of the common people."

It can also be seen that during the $20_{\text {th }}$ century, the understanding that basic human needs such as economic necessities (the need of food, housing, etc.)-have to be aligned with the "natural rights", has continuously arise and trigger the obligation for State to protect the aforementioned rights and for those rights to be labeled as human rights. Therefore, there should be no difference between the $\mathrm{CP}$ rights and the ESC rights. Some of the misguided understandings have to be straightened immediately to give both rights the same amount of attention. 


\section{General Idea on the Differences between CP Rights and ESC Rights}

ICESCR, ICCPR, as well as UDHR are the main pillars of the protection of human rights. ICESCR reflects the commitment taken after the World War II to promote the positive improvement on social and livelihood standard. Mapulanga-Hulston (J.K Mapulanga-Hulston, 2002 : 29-48) stated that the category for these rights constitutes rights with humanitarian nature and aims to provide basic rights to individuals to live with dignity, since someone can be seen as undignified without any job, in the state of famine, sick, has no housing, and has never been taught any proper education.

The segregation of rights - known as "first-generation human rights" and "second-generation human rights"-has led to the mistaken comprehension on the superiority of the first-generation human rights to the secondgeneration human rights. This inaccurate terminology has further created the wrong conception that the second-generation human rights, the ESC rights, are being treated as "second-class rights". This terminology also played a significant amount of influence on the implementation on the ESC rights.

There are several general standpoints on the differences between the two generations of human rights, such as:

(a) In the different diction of Article 2 of ICCPR (Each State Party to the present Covenant undertakes to respect and to ensure to all individuals within its territory and subject to its jurisdiction the rights recognized in the present Covenant, without distinction of any kind, such as race, colour, sex, language, religion, political or other opinion, national or social origin, property, birth or other status) and Article 2 of ICESCR (Each State Party to the present Covenant undertakes to take steps, individually and through international assistance and co-operation, especially economic and technical, to the maximum of its available resources, with a view to achieving progressively the full realization of the rights recognized in the present Covenant by all appropriate means, including particularly the adoption of legislative measures).

Relating to the implementation of the two categories of human rights, it can be concluded that $\mathrm{CP}$ rights are absolute and the implementations have to be immediate, whereas the implementation of the ESC rights can be achieved gradually thus can also be seen as a distinction of the CP rights. In practice, there are several industrially developed countries which regard the ESC rights as "aspiration" of the people and can be satisfied by state policies (DJ Harris, 2004 : 655). For example, the American Government in 1982 deleted the economic, social, and cultural section from its annual Country Reports on Human Rights Practices delivered in front of the US Congress 
1982, with argumentation from the assistant to the Secretary of State which stated that no state "can violate" any CP rights yet any government "should do their best to secure" the fulfillment of any ESC rights. (Okeowo Ademola Oladimeji, "Economic, Social and Cultural Rights: Rights or Privileges?", Available at: http://ssrn.com/abtract=1320204).

(b) In regards to justiciability, many arguments stated that the fulfillment of $\mathrm{CP}$ rights are easy to attain through appropriate judicial and/or other legal channels, whereas the political nature in satisfying the ESC rights leads to a non-justiciable condition which preventing any fulfillment request to the State. The argument on the non-justiciability of ESC rights arose from the understanding that no legal channels are capable on adjudicating any claims relating to ESC rights (Azizur Rahman\&Md. Jahid Hossain (eds.), 2010 : 54). Consequently, this condition is largely influenced by the political policies issued by both the executive and legislative branch of the government. Court or any supervisory board on human rights are unable to take over the policy-making function of the government on policies regarding the ESC rights.

(c) It is often seen that $\mathrm{CP}$ rights are more focused on individual, which further developed an individualistic nature, whereas the ESC rights frequently discussed on a specific group or community and therefore have a more collective nature.

(d) Based on the general view of the public, the fulfillment of $\mathrm{CP}$ rights requires no cost, yet the same thing cannot be said for the ESC rights. The fulfillment of $\mathrm{CP}$ rights is emphasized on the lack of governmental intervention on individual freedom. On the contrary, the implementation of ESC rights entails a huge amount of cost due to the state obligation to ensure the wellbeing of its people (A. Eide, 2001 : 10). As stated by Baderin and McCorquodate: (Mashood A. Baderin and Robert McCorquodale, 2007 :12).

"A related argument to that of non-justiciability was the view that, unlike CP rights that mostly required 'negative obligations' on the part of states, ESC rights required 'positive obligations' on the part of states to fulfill them and consequently, ESC rights were more resource demanding than $\mathrm{CP}$ rights, and so could only be progressively implemented depending on the availability of resources. The obligations of states parties are recognized under the ICESCR as being subject to the availability of resources and require only the 'progressive realization' of the recognized rights."

(e) Several scholars have argued that whenever a violation of CP rights occurs, it is easy to deduce the victim, the perpetrator, and the compensation it requires. 
Quite the contrary, it would take more effort to determine the parameters on a violation of ESC rights. This argument has also been written in the Economist: (Okeowo Ademola Oladimeji, Loc.Cit)

"...when a government locks someone up without a fair trial, the victim, perpetrator and remedy are pretty clear. This clarity seldom applies to social and economic "rights". It is hard enough to determine whether such a right has been infringed, let alone who should provide a remedy, or how..."

As a matter of fact, the aforementioned standpoints on the difference between $\mathrm{CP}$ rights and ESC rights cannot be qualified as the right standpoint, mainly because not every right that fall under the ESC rights are deemed nonjusticiable, such as the right to occupation. The fulfillment for the right to occupation can be fully brought to the appropriate court should there be any violation within its fulfillment. The differentiation between the two generations of human rights which constructed from the availability of the resources can also be deemed incorrect since every States will need any available resources they have to implement all types of human rights.

\section{The Justiciability of Economic, Social, and Cultural Right: The Court Enforcement Mechanism (Case Study: South Africa)}

ICESCR 1966, which entered into force in 1976 simultaneously with ICCPR, is a covenant consisting of fundamental human rights which aims to ensure the protection of human rights. ICESCR has been acknowledged and welcomed by the vast majority of the world. Based on the data in the UN, by 2016 ICESCR has 164 State Parties. (http://www.ohchr.org/en/hrbodies/cescr/pages/cescrindex. aspx) It shows that States have begun to be aware with the importance of ESC rights in the same way that $\mathrm{CP}$ rights are.

With an immense number of State Parties, one would assume that the realization of ESC rights will amount to the same realization of $\mathrm{CP}$ rights. Such assumption soon leads to query on how the ESC rights can be fulfilled? What if the recognition of the ESC rights will only in in written text without any enforceable compliance? It should also be concerned that State Parties may not always try to satisfy the ESC rights due to the diction "progressive realization to the maximum available resources" of the covenant. One of the most important aspects is also regarding how the nationals of the State Parties can claim for the fulfillment of their rights.

South Africa is one of the leading States in the protection of ESC rights. Quite contradictory with the common State practices which barely recognize the justiciability of ESC rights, South African Government had explicitly included 
the ESC rights to its constitution after the apartheid system. Furthermore, the recognition of the justiciability of the ESC rights has also been indicated in several landmark cases decisions.

The Constitution of the Republic of South Africa [Act No. 108 of 1996] is widely known as the most progressive constitution in the world. (Jackie Dugard, 2007) Chapter 2 of the Constitution (sections 7-39) contains the fundamental rights with the combination of both the CP rights and the ESC rights. The fundamental rights are recognized in strictly justiable manner, as stated in several provisions such as:

a. Section 7(2): "The State must respect, protect, and promote and fulfil the rights in the Bill of Rights".

b. Section 8(1): "The Bill applies to all law, and binds the legislature, the executive and the judiciary and all organs of the state".

c. Section 38: "Anyone listed in this section has the right to approach a competent court, alleging that a right in the Bill of Rights has been infringed or threatened, and the court may grant appropriate relief, including a declaration of rights".

Specifically, the Constitution does not separate the first-generation human rights with the second-generation human rights. The consequences arising from this circumstance is the condition in which the people can also claim for the fulfillment for the second-generation human rights through court and this has also been guaranteed by the South African Constitutional Court. (Ellie Palmer, tahun : 43) The Constitutional Court stated its argument that the ESC rights are not always a requisite for a bill of rights due to their relation with policy-making and budgetary issues along with the impact on the separation of power, as stated:

"In our view, it cannot be said that by including socio-economic rights within a bill of rights, a task is conferred upon the court so different from that ordinarily conferred upon them by a bill of rights that it results in a breach of separation of powers... These rights are, at least to some extent, justiciable. As we have stated ... many of the civil and political rights entrenched in the [Constitution] will give rise to similar budgetary implications without compromising their justiciability ... The fact that socio-economic rights will almost inevitably give rise to such [budgetary] implications does not seem to us to be a bar to their justiciability."

The Constitution further expresses that any appropriate court must be mindful of international law provisions in presiding any claims and interpreting any fundamental rights under its judgment. Section 39 on the Constitution regulates that in regards to interpretation, "a court, tribunal or forum must consider 
international law" and "may consider foreign law". In practice, the human rights law and comparative case studies hold an important role in the decision of the Constitutional Court. The Constitutional Court also stated that in interpreting the fundamental rights in the Constitution, it may consider any binding or non-binding provisions in international law.

“..... public international law would include non-binding as well as binding law. They may both be used under the section as tools of interpretation"

Additionally, the Constitution firmly states the positive obligation for the State to realize the fundamental rights of its nationals. As regulated in Section $7(2)$, the State must fulfill its obligation to implement the fundamental rights by respecting, protection, and promoting the bill of rights. The positive obligation is further shown by the provisions on taking legislative measures ensure the fulfillment of the fundamental rights by using any available resources. Take Section 26 and 27 of the Constitution for instance, in which the State is obliged to take reasonable legislative measures to fulfill the right to housing and the right to heatlh, including but not limited to the right to reproductive health care, the right of sufficient food, and the right to social security.

The fundamental rights under the Constitution of South Africa may be formulated into three main characteristics (Ellie Palmer, tahun : 41) mainly based on the different responses from the court. First characteristic is the basic rights, which unlike the rights embodied in the ICESCR; the basic rights are neither constrained by any programs nor any resources to implement the rights. Second characteristic is the economic and social rights such as: the right to adequate housing, the right to healthcare, the right to sufficient food and water, and the right to social security. In this second characteristic, the State is expected to take legislative and other measures by using the available resources to fulfill the progressive implementation of the aforementioned rights. Third characteristic is the negative rights, which prohibit the State to intervene the fulfillment of the rights. As can be seen in Section 26 on the right of adequate housing, there is no legislation permitting any arbitrary evictions by the State to any of its nationals. Therefore, the bill of rights in the Constitution-whether the CP rights or ESC rights - may be subjected to certain limitations. The Constitution regulates that any limitations may only be determined by appropriate law insofar as they are justified under the notion of democratic society based on the equity and dignity of human being as well as personal freedom. 


\section{The Justiciability of Economic, Social, and Cultural Right in Indonesia and Its Prospect of Implementation}

The justiciability of $\mathrm{CP}$ rights has been relatively known and exercised in Indonesia. For instance, any victims or family of victims from abuse or arbitrary arrest may ask the court to try the perpetrator and rule a just judgment for any remedy legally obtainable by the victims and/or their family, such as: restitution, compensation, or rehabilitation.

The practice of seeking remedy by the victims and/or their family has often occurred in human rights violation cases. In 2002, the Indonesian Government has issued the Government Regulation Number 3 of 2002 on The Compensation, Restitution, and Rehabilitation of Human Rights Violation Victim (Peraturan Pemerintah Nomor 3 Tahun 2002 tentang Kompensasi, Restitusi, dan Rehabilitasi untuk Korban Pelanggaran Hak Asasi Manusia). The formulation of this regulation is based on the same provisions under Law Number 26 of 2000 on the Human Rights Court (Undang-Undang Nomor 26 Tahun 2000 tentang Pengadilan Hak Asasi Manusia). Specifically, in 2008 government has enacted Government Regulation Number 44 of 2008 on the Compensation, Restitution and Assistance for Witnesses and Victims (Peraturan Pemerintah Nomor 44 tahun 2008 tentang Pemberian Kompensasi, Restitusi dan Bantuan pada Saksi dan Korban).

In 2004, The Human Rights Ad Hoc Court delivered a judgment on the human rights violation in Tanjung Priok. This judgment is one of the most important jurisprudence in human rights cases, wherein it was decided that the victims are entitled to compensation. Based on the aforementioned case, it can be concluded that: (1) compensation, restitution, and rehabilitation have been recognized as the remedy for the victims of any human rights violation; and (2) the presiding judge in the Tanjung Priok case had showcased and recognized the justiciability of human rights.

Subsequently, it comes to question on the justiciability of the ESC rights. Is there any claim or lawsuit regarding the fulfillment of ESC rights in Indonesia? Herewith are some of the principal ESC rights in Indonesia along with their justiciability practices.

a. Right to Education

Education is one of the human rights under the ESC rights category The formulation of education as part of the human rights is evident in Article 26 paragraph (1) of UDHR which states:

"Everyone has the right to education. Education shall be free, at least in the elementary and fundamental stages. Elementary education

460 Yustisia Vol. 7 Number 3 (Sept.-Dec. 2018) Justiciability Of Economic, Social ... 
shall be compulsory. Technical and professional education shall be made generally available and higher education shall be equally accessible to all on the basis of merit."

The right to education has also been specifically embodied in Article 13 and 14 of ICESCR. As aforementioned beforehand, Indonesia as State Party to the ICESCR (ratification through Law Number 11 of 2005) has an obligation to exercise this provision. Article 13 and 14 of ICESCR do not only regulates the right to education for the people, but also impose a state obligation to fulfill the aforesaid right. Article 13 paragraph (1) of ICESCR states:

"The states Parties to the present Covenant recognize the right of everyone to education. They agree that education shall be directed to the full development of the human personality and the sense of its dignity, and shall strengthen the respect for human rights and fundamental freedoms. They further agree that education shall enable all persons to participate effectively in a free society, promote understanding, tolerance and friendship among all nations and all racial, ethnic or religious groups, and further the activities of the United Nations for the maintenance of peace".

The provision under Article 13 paragraph (2)(1) further elaborates that primary education shall be compulsory and the State has an obligation to fulfill the said provision: "The states parties to the present covenant recognize that, with a view to achieving the full realization of this right: (a) primary education shall be compulsory and available free to all".

Moreover, the general comment on Article 13 of ICESCR (right to education) also clarifies the provision of the article by stating:

"Education is both a human right in itself and an indispensable means of realizing other human rights. As an empowerment right, education is the primary vehicle by which economically and socially marginalized adults and children can lift themselves out of poverty and obtain the means to participate fully in their communities. Education has a vital role in empowering women, and safeguarding children from exploitative and hazardous labour and sexual exploitation, promoting human rights and democracy, protecting the environment, and controlling population growth. Increasingly, education is recognized as one of the best financial investment's states can make. But the importance of education is not just practical: a well-educated, enlightened and active mind, 
able to wander freely and widely, is one of the joys and rewards of human existence"

The scope of right to education under the ICESCR General Comment No. 13 is examined under four principles, namely: availability, accessibility, acceptability, and adaptability. These four principles will be used as indicators on understanding how the right to education under ICESCR shall be fulfilled. (Manisuli Ssenyonjo, 2009: 386-390)

1) Availability principle

The availability principle relates to the responsibility of State to ensure the availability of institutions and educational programs along with their facilities to exercise the right to education (such as: educational buildings, sanitation facilities, clean water facilities, teachers with excellent credibility, teaching materials, etc. along with facilities such as computers, libraries, and information technologies). In ensuring the availability of education for its people, the Government has to both permit the construction of educational buildings and allocate appropriate resources to develop the educational institutions. This obligation urges a governmental obligation to allocate sufficient amount of effective schools to avoid the disparity between the quantities of students to available classrooms and to repudiate any declines on the quality of education.

2) Accessibility principle

The accessibility principle indicates that education shall be accessible and open to anyone. ICESCR states that there are 3 (three) components to this principle. First, education shall be accessible to anyone without any discrimination. The CESCR Committee further obliges the Government to ensure the participation of all young girls in education, mainly due to the old-fashioned perspective that young girls are prohibited to receive any formal education and should only be allowed to stay at home. To ensure the participation of young girls in formal education, the Government could issue several policies on providing intensive programs for parents to arrange education for their children or to increase the minimum age of marriage thus allowing children to finish their education first. Additionally, Article 13(e) of ICESCR specifies that "... an adequate fellowship system shall be established...", in which the fellowship shall be provided with non-discrimination and fairness. The fellowship system shall increase the accessibility of education especially to individuals from "the most vulnerable groups", including children and women. 
Second, education shall be physically accessible to anyone. This component establishes that school buildings have to be available in strategic locations to make sure that everyone living in the area of the locations, including the area around the locations or the area where the most vulnerable groups reside, will be able to participate. The real example of this component is to build school buildings in the location of an indigenous people and to provide both transportation accesses for other specific groups along with the technologies to help with the teaching process. Should there be a situation when either natural disaster or armed conflict occurs; the State has to prepare a distinctive attention to the state of education, particularly because both children and the most vulnerable group are often stripped off of their access to education. (Gay McDougall : para. 32)

Third, education shall be affordable to anyone with any economic background. Nevertheless, the conditions that education shall be free are subject to the exceptions as regulated in Article 13(2) of ICESCR, specifically for primary education, secondary education, and higher education. In relation to the primary education, the State Parties which have yet to provide free education for the primary education when they are bound by the ICESCR must implement appropriate programs no later than 2 (two) years after the ratification to ensure the free primary education for the people.

3) Acceptability principle

The acceptability principle is related to the quality of any form and/or substances of the education. This principle holds both human dignity and human equity, thus ensuring that the education provided by the State shall consists of the highest quality and shall be beneficial to individuals, communities, along with the neighborhoods. This principle is based on Article 13(2) of ICESCR which expresses that the materials for the teaching staff shall be continuously improved.

4) Adaptability principle

The adaptability principle indicates that education has to be flexible to ensure that it is capable to respond the vast demands of students from all social and cultural background. To assure the adaptability of the education, the Government shall prepare the proper resources for schools to develop the education plans to fulfill the right to education. The condition in which an education system fails to adapt to any developments will often results in a high amount of drop-out students. The CESCR Committee underlines that education must be flexible to not 
only adapt to the ever-changing needs of the people, but also to respond to any demands arising from the people.

The four aforementioned principles shall be applied to determine whether the fulfillment of the right to education complies with the provisions under ICESCR or not. This condition shall further be used to ensure that the main purpose of ICESCR to protect the right to education has been appropriately exercised.

In Indonesia, the recognition to the right to education has been noted in the 1945 Constitution of Indonesia (Undang-Undang Dasar 1945) long before the ratification of ICESCR (with Law Number 11 of 2005). Article 28c paragraph (1) of the 1945 Constitution regulates:

"Setiap orang berhak mengembangkan diri melalui pemenuhan kebutuhan dasarnya, berhak mandapat pendidikan dan memperoleh manfaat dari ilmu pengetahuan dan teknologi, seni dan budaya, demi meningkatkan kualitas hidupnya dan demi kesejahteraan umat manusia."

Additionally, several other national legislations have also elaborated the importance of the right to education; for example, Law Number 39 of 1999 on Human Rights (Undang-Undang Nomor 39 Tahun 1999 tentang Hak Asasi Manusia, hereinafter Law of Human Rights) and Law Number 20 of 2003 on National Education System (Undang-Undang Nomor 20 Tahun 2003 tentang Sistem Pendidikan Nasiona, hereinafter Law on National Education System). Article 12 of Law on Human Rights regulates that: "setiap orang berhak atas perlindungan bagi pengembangan pribadinya, untuk memperoleh pendidikan, mencerdaskan dirinya, dan meningkatkan kualitas hidupnya agar menjadi manusia yang beriman, bertaqwa, bertanggung jawab, berakhlak mulia, bahagia dan sejahtera sesuai dengan hak asasi manusia." Subsequently, Law on National Education System specifically regulates the right to education, insofar as to ensure the protection and fulfillment of the right to education for children in need. (Article 12 of the Law on National Education System)

In practice, the justiciability of the right to education may be evaluated from the judicial review decision of the Constitutional Court on the Law on National Education System. Notwithstanding the fact that not every technical aspects of the exercise of the right to education is included in the judicial review, the practice on justiciability of the right to education alternatively includes a much greater subject - the $20 \%$ supposed-allocation of the State Budget (Anggaran Pendapatan dan Belanja Negara-APBN) for the education funding. 
The judicial review for the Law on National Education System and Law Number 2006 on State Budget (Undang-Undang Nomor 2006 tentang Anggaran Pendapatan dan Belanja Negara, hereinafter Law on State Budget 2006) was submitted by Dra. Hj. Rahmatiah Abbas (teacher from Kabupaten Wajo) and Prof. Dr. Badriah Rifai (professor of the Faculty of Law, Universitas Hasanuddin, Makassar). The applicants deemed the Article 49 paragraph (1) of Law on National Education System, that stated "Dana pendidikan selain gaji pendidik dan biaya pendidikan kedinasan dialokasikan minimal 20\% dari Anggaran Pendapatan dan Belanja Negara (APBN) pada sektor pendidikan dan minimal 20\% dari Anggaran Pendapatan dan Belanja Daerah (APBD)", violated Article 31 paragraph (4) of the 1945 Constitution ("Negara memprioritaskan anggaran pendidikan sekurang-kurangnya $20 \%$ dari anggaran pendapatan dan belanja Negara serta dari anggaran pendapatan dan belanja daerah untuk memenuhi kebutuhan penyelenggaraan pendidikan nasional.") for excluding the component of teachers' and lecturers' salary from the State Budget. The judgment for this judicial review was ruled on February 20 $0_{\mathrm{th}}, 2008$ by granting the review of Law on National Education System; however, the application to review the Law on State Budget with the 1945 Constitution was overruled. The Constitutional Court, through its Judgment Number 24/PUUv/2007, concluded that the claim submitted by the applicants regarding Article 49 paragraph (1) of Law on National Education System insofar as related to the phrase "educators' salary" has a probable cause and thus shall be granted.

As a result of the abovementioned judgment, the educators' salary-as part of the education components - shall be included in the drafting of the education funding under the State Budget and the Regional Government Budget (Anggaran Pendapatan dan Belanja Daerah-APBD). This decision shall be exercised throughout Indonesia immediately after it is ruled. Should the allocation of the education funding be less than $20 \%$, it may be seen as a violation of the 1945 Constitution and the minimum funding allocation shall also be at $20 \%$, therefore a developing States may allocate the education funding up to $30-40 \%$ but the allocation shall not be less than $20 \%$ (In accordance with Article 31 paragraph (4) of the 1945 Constitution).

The Constitutional Court further elaborates that by adding the educators' salary component in the allocation of education funding, it will also aid both the Government and the House of Representatives (Dewan Perwakilan Rakyat$D P R$ ) in exercising their obligations to allocate at least $20 \%$ of the State Budget for the education funding. Provided that the educators' salary component is excluded from the State Budget, the education funding will only 
amount to $11,8 \%$; whereas when the educators' salary component is added, the total education funding in the State Budget 2007 will arise up to $18 \%$.

In relation to the addition of the educators' salary to the $20 \%$ education funding, the author would like to express different opinion. According to the author, adding the educators' salary to the education funding will only result in an even smaller funding allocation for education. Ideally, the $20 \%$ funding shall only be utilized to improve the resources for education as well as increasing the quality of the education. Consequently, the $20 \%$ funding allocation in the State Budget for education purposes is expected to extend not only to those in needs, but also to the people all across remote areas in Indonesia. Should the education access and/or availability is evenly conducted throughout Indonesia, the Government could begin to specifically improvise not only the standard but also the quality of education. (Nihal Jayawickrama , 2002: 896) In other words, with a total State Budget allocation of $20 \%$ purely for the educational process, the Government shall be free to fulfill the right to education for its people.

b. Right to housing

The international community has taken measures to ensure the protection and realization to the right to housing since long ago. This right has also been explicitly included in the ICESCR (Article 11(1) of ICESCR, further elaborated in General Comment No. 4). The CESCR Committee through its General Comments No. 4 elaborates the basic principles in the fulfillment of the right to housing, as follows:

1) Accessibility principle. This principle stipulates that everyone is entitled to adequate housing and elaborates that the fulfillment of housing is determined by its priorities, such as access to adequate housing for disadvantaged groups and/or communities as well as vulnerable communities in the likes of the elders, children, people with disabilities, and chronically-diagnosed people;

2) Affordability principle. In general, this principle aims to ensure that everyone shall be able to afford adequate housing. Therefore, the pricing for adequate housing shall be affordable to anyone; and

3) Habitability principle. This principle specifies the prerequisite for an 'adequate' housing. This principle also indicates that any housing shall have appropriate space to protect the inhabitants from any types of weathers, be it heat, rain, and other threats to health.

Alongside the aforementioned principles, other international conventions have also regulate other principles in the fulfillment of the right to housing, 
for example: there shall be no discrimination on race, skin color, nationality, or ethnic origins (See UN Doc. Covention on the Elimination of All Forms of Racial Discrimination (CERD), art. 5(e) (iii)) in exercising the right to housing; there shall be equality between men and women; and there shall be facilitation in order to aid any parents in fulfilling the right to housing for their children. (UN doc. Convention on the Rights of the Child (CRC)., art. 27 (3)) International Labour Organization (ILO) has also adopted 2 (two) conventions in regards to the right to housing. (ILO Convention No. 169 Concerning Indigenous and Tribal Peoples and No. 161 concerning Occupational Health Services (1985)) Accordingly, the fulfillment on the right to housing for refugees is also regulated in the International Convention Relating to the Status of Refugees 1951.

In Indonesia, the measure to protect the right to housing is expressively regulated in Article $28 \mathrm{H}$ paragraph (1) and (4) of the 1945 Constitution, as follows:

(1) Setiap orang berhak hidup sejahtera lahir dan batin, bertempat tinggal, dan mendapatkan lingkungan hidup baik dan sehat serta berhak memperoleh pelayanan kesehatan.

(4) Setiap orang berhak mempunyai hak milik pribadi dan hak milik tersebut tidak boleh diambil secara sewenang-wenang oleh siapapun.

Furthermore, it is stated under the consideration of the Law Number 4 of 1992 on Housing and Residence (Undang-Undang Nomor 4 Tahun 1992 tentang Perumahan Pemukiman) that: "pembangunan manusia Indonesia seutuhnya dan pembangunan seluruh masyarakat Indonesia, perumahan dan permukiman yang layak, sehat, aman, serasi dan teratur merupakan salah satu kebutuhan dasar manusia dan merupakan faktor penting dalam peningkatan harkat dan martabat, mutu kehidupan serta kesejahteraan rakyat dalam masyarakat yang adil dan makmur" (The Consideration letter (a) of Law Number 4 of 1992 on Housing and Residence) and Article 5 strictly regulates the right to housing, as stated that "Setiap warga Negara mempunyai hak untuk menempati dan/atau menikmati dan/atau memiliki rumah yang layak dalam lingkungan yang sehat, aman, serasi, dan teratur." The 'adequate housing' under this Law refers to buildings with physical safety guarantee, appropriate minimum space for living, and protection from other threats of health and/or diseases to the inhabitants. Consequently, a healthy, safe, harmonious, and well-regulated environment refers to territories which satisfy the spatial planning requirements, land use requirements, land ownership requirements, as well as appropriate infrastructures and facilities 
around the neighborhood. (The Explanation of Article 5 of Law Number 4 of 1992 on Housing and Residence)

Subsequently, there comes a question on whether Indonesia has fulfilled its obligation under ICESCR in regards to the right to housing. In practice, forced evictions by the authorities have occurred one too many times and resulted in nothing but harming the people, especially those living under poverty. According to a report prepared by Human Rights Watch entitled "Masyarakat yang Tergusur: Pengusiran Paksa di Jakarta" Volume 18 No. 10, September 2006; during the 9-year ruling of then-Governor of Jakarta Sutiyoso, hundreds of people were victims to forced evictions and the destruction of their properties. These actions were organized by the local government and were executed by local police, security officers, alongside the military personnel. Furthermore, there had been traces of private companies aiding the authorities in executing the aforementioned actions. On numerous occasions, the eviction was executed without any due process and the victims had little to no idea that they will be evicted from their household, let alone a compensation for their home. In this case, the Jakarta Government often justified their actions by noting that these evictions were conducted to infrastructure projects. Concurrently, other households were also demolished under the pretense to eradicate slum areas for public order, or to relocate the people who unlawfully inhabit any private or State-owned land. The forced eviction practices have yet to be eliminated even in 2016, where forced evictions still occur whether in the capital or other towns all around Indonesia.

In regards to the forced evictions in Indonesia, despite the fact that the people unlawfully inhabit the territory, they are not to be treated in arbitrary manners. Indonesia has strictly recognized the freedom of movement, migrate, and reside in the territory of Indonesia (Article 27(1), as stated in Article 13 of UDHR) under the Law on Human Rights; alongside the right not to be deprived of property as regulated in Article 36 paragraph (2). The exception to this provision is elaborated in Article 37 paragraph (1) which regulates that deprivation of property for public order may only be exercised with appropriate and immediate remedy with due process based on the legislations.

As might be seen, the ratification of ICESCR by Indonesia ideally formed a Governmental obligation to ensure that the Government must provide adequate housings for its nationals who have yet to enjoy their right. The State has to repudiate in arbitrarily taking over any unlawful households 
belonging to its people and instead focuses on how to find solutions to any issues regarding to housing.

Evidently, there are challenges in the actualization of ESC rights (Yuval Shany, 2006, www.ssrn.com/abtract=920753), largely due to the dictions in the ICESCR in describing its scopes and State obligations in realizing the entitled rights under the covenant which led to different interpretation and the increase of incredulity in the justiciability of the ESC rights. Some particular challenges in the actualization of ESC rights are as follows:

1) A rather loose formulation of the rights, in which a vast amount of ESC rights is viewed with a flexible standard of law along with insufficient number of guidelines for State Parties. For example, Article

9 of ICESCR protects the right to social security, including insurance; Article 11 protects the right to adequate standard of living for himself and his family, including adequate food, clothing, and housing, and to the continuous improvement of living conditions; Article 12 includes the right to enjoyment of the highest attainable standard of physical and mental health. Although some of the first-generation human rights are also formulated in a rather ambiguous pattern, the practice in recognizing the first-generation human rights are implicitly regulated in any national law system.

2) The freedom to decide on implementation method. Article 2(1) of ICESCR stated that the realization of the entitled rights under the covenant may be exercised by 'all appropriate means. The same diction is also used in several other articles under the ICESCR, which led to the freedom on deciding how the implementation of SCR rights may be pursued.

3) Relativity. All SCR rights under the ICESCR are related to the provision in Article 2(1) on the State Parties responsibility to implement the SCR rights and to provide the maximum of its available resources. Furthermore, Article 4 also allows the limitation of SCR rights under the notion of public order in a democratic society.

4) The progressive fulfillment of ESC rights. As stated in Article 2(1) of ICESCR, State Parties may progressively achieve full realization of SCR rights embodied in the ICESCR. The statement on progressive fulfillment can also be seen in several articles under the covenant.

The combination of flexibility, the vast freedom, the limitation, and the uncertainty on the implementation of ESC rights have led to the assumption that the rights under ICESCR are merely an aspiration with no legal consequences. 
In the meantime, Indonesia encounters similar challenges in implementing the SCR rights under ICESCR. Consequently, in practice, the extensive number of legislations and/or regulations in Indonesia does not guarantee the realization of the SCR rights. This condition may be caused by the following predicaments: (Suparman Marzuki, 2007)

1) The legislative drafting process in Indonesia is often done reactively and rushed, resulting in contradictory nature between the legislation and the current state of the people. Moreover, some of the legislations which have yet to be fully implemented are already been proposed to be amended.

2) The delegation nature of law administration (Constitution, Law/Act, Government Regulation, Ministry Regulation, Implementation Guideline [Petunjuk Pelaksanaan], Technical Guidelines [Petunjuk Teknis], etc.) has led to at least 3 (three) conditions: (1) the case of reduction in the regulation substances, insofar as different interpretation under Law/Act and Government Regulation; (2) the delayed implementation of Law/ Act due to the impending Government Regulation, Implementation Guideline, or Technical Guideline; and (3) the meandering administrative process in implementing any Law/Act by the authorities.

3) The administrative system for legislations in Indonesia is in an uncertain situation, leading to overlapped, duplicated, and even contradicted legislations and/or regulations in practice.

4) The influence of then-authoritative power in a centralistic, indistinct, immeasurable, and uncertain manner can still be found in the current legislations and/or regulations. The use of "may" (dapat), "to the maximum extent possible" (semaksimal mungkin), "attempt"

(diupayakan), "upholding" (menjunjung tinggi), etc. are still to be found in several provisions under articles in effective legislations and/ or regulations.

5) Law/Act and other legislations henceforth with a funding and/or facilitate consequences from the State (government) is usually formulated in a tight manner with inconvenient procedures and mechanisms which led people to forgo the implementation, especially the later halves of the society.

6) Almost all articles regarding the ESC rights in Indonesia are considered as 'soft law' and barely recognized as a moral exclamation with little to no legal standing in court whenever a right is neglected or even when a violation occurs. 
7) The Government and the House of Representatives seem to not fully understand the substance of ESC rights. Both authorities have yet to recognize that the ESC rights are designed to ensure the thorough protection of human beings based on a notion that all human beings are entitled to relish their rights, freedoms, and social justice simultaneously. Both authorities have also yet to understand that the ICESCR has modified the 'needs' into 'rights' based on the equity and morality of human beings. This circumstance leads to the feasibility for the people to construct their basic needs a "right to claim" and not a "charity to receive".

Subsequently, the prospect of justiciability regarding ESC rights in Indonesia is still a matter to be questioned. This matter is pertaining to what measures the Government could take in exercising the ESC rights. Some particular measures for the Government are as follows:

1) To ensure that other international conventions related to the ESC rights are ratified.

2) To include the elements of ESC rights into the national legislations, as recommended in the CESCR Committee General Comment No. 9.

3) To create a complaint mechanism which allows any claim for a violation to the ESC rights by non-state actors, including but not limited to international organization, transnational corporation, along with individuals, to ensure the remedy for the victims and/or their family.

4) To ensure the adoption of Optional Protocols to the ICESCR to assure that any individuals may apply for a claim to the CESCR Committee.

5) To generate a more effective complaint or judicial mechanism alongside the realization of the ESC rights in national level.

6) To provide due process and appropriate legal aid for the victims of ESC rights violations until the victims obtain the adequate remedies.

7) To guarantee that the national human rights institution held an obligation to investigate any possible claims of violations of ESC rights and to try the claims in the authorized judicial bodies along with promoting conformity with the ICESCR.

8) To ensure that any judicial decisions will maintain a consistency and the ESC rights will be respected, implemented, and the mechanism to fulfill the ESC rights will always be developed. 


\section{E. CLOSING:}

\section{E.1. Conclusion:}

1. Fundamentally, the International Law of Human Rights has recognized the justiciability of ESC rights as a counterpart of the CP rights. This notion has been regulated in several essentials' international conventions on human rights. In general, international law imposed 3 (three) main obligations onto State, particularly regarding the ESC rights, which are the obligations "to respect, protect, and fulfill". The obligation "to respect" instructs States to refrain or to avoid intervening in the fulfillment of ESC rights, for example the right to adequate housing has been violated when the Government conducted a forced eviction. The obligation "to protect" commands States to prevent any violations of the ESC rights by third parties, such as by trade companies or individuals as well as preventing parents to prohibit their young daughters to get formal education. Subsequently, the obligation "to fulfill" orders the Government to take legislative, administrative, and judicial measures to realize the ESC rights.

2. The practice throughout the world in the justiciability of the ESC rights has begun to develop. One of the leading practices is by South Africa as the most progressive State in ensuring the protection and fulfillment of ESC rights. Up until now, The Constitutional Court of South Africa has ruled 5 (five) judgments regarding any claims the people have submitted due to the violation of ESC rights, specifically the right to health and the right to education. Whereas in Indonesia, the claims on violation of ESC rights have yet to be formally submitted to any judicial authorities. The abovementioned judgment - as ruled by The Constitutional Court of Indonesia - is related to the right to education, nevertheless the substance of the claim did not relate to the fundamental substance of the right to education.

\section{E.2. Suggestions:}

In addition, the author would like to address several issues as suggestion as follows: first, it is time for every citizen of Indonesia to understand and to promote the protection of ESC rights, as well as persuade the urgency for the justiciability of the ESC rights by the Government. The justiciability of the ESC rights incorporates the prospect for the people to use judicial mechanisms as the means to protect and to fulfill the ESC rights by utilize the claims or to examine the ESC rights under the court or other alternative judicial mechanism, such as mediation. Second, all members of society shall begin to monitor the progressive measures taken by the State in realizing the ESC rights to prevent the avoidance by the Government in exercising its obligation. For instance, in the fulfillment of the right to adequate housing, the people could monitor the construction of public housing for those with limited income and to further review the State policies regarding the right to housing, such as housing loans/credits. The aforementioned monitoring shall also be associated

472 Yustisia Vol. 7 Number 3 (Sept.-Dec. 2018) $\quad$ Justiciability Of Economic, Social ... 
with funding and budgeting allocation, both in local/regional or national level. Lastly, it is about time that the Government of Indonesia should strongly consider in adopting the Optional Protocols to the ICESCR which will allow individuals to file a complaint for any violations of the ESC rights. Should the Government finally adopt the protocols, this act will further prove the good faith and active measures taken by the Government in ensuring the rights of its people, particularly by recognizing the justiciability of the ESC rights.

\section{BIBLIOGRAPHY:}

\section{Legal Documents/Regulations:}

International Covenant on Civil and Political Rights 1966 International

Covenant on Economic, Social and Cultural Rights 1966

The Limburg Principles on The Implementation of The International Covenant on Economic, Social and Cultural Rights

The Maastricht Guidelines on Violations of Economic, Social and Cultural

Rights UN doc. CESCR. General Comment No. 4 (1991),

UN doc. Convention on the Elimination of All Forms of Discrimination Against Women (CEDAW)

UN doc. Convention on the Rights of the Child (CRC)

ILO Convention No. 169 Concerning Indigenous and Tribal Peoples dan No. 161 concerning Occupational Health Services (1985)

"Prinsip dan Pedoman Dasar mengenai Penggusuran dan Pengusiran Berdasarkan Alasan Pembangunan”, E/CN.4/2006/41, 14 Maret 2006

\section{Books:}

A. Eide, 2001, Economic, Social and Cultural Rights as Human Rights, in A. Eide, C. Krause \& A. Rosas (eds.), Economic, Social and Cultural Rights: A textbook, 2nd Revised Edition, Martinus Hijhoff Publishers.

Azizur Rahman\&Md. Jahid Hossain (eds.), 2010, An Introduction to International Human Rights Law, Brill: Leiden

D.J Harris, 2004, Cases and Materials on International Law, 6th edition, Sweet and Maxwell.

Ellie Palmer, 2007, Human Rights Law in Perspective, "Judicial Review, SocioEconomic Rights and the Human Rights Act, Hart Publishing: Oxford and Portland,.

Yustisia Vol. 7 Number 3 (Sept.-Dec. 2018)

Justiciability Of Economic, Social ... $4 \mathbf{4 7 3}$. 
Ifdal Kasim and Johanes da Masenus Arus, 2001, Hak Ekonomi, Sosial, Budaya: esai-esai pilihan, ELSAM: Jakarta..

Manisuli Ssenyonjo, 2009, Economic Social and Cultural Rights in International Law, Hart Publishing: Oxford \& Portland, Oregon,.

Matthew Craven, 1998, The International Covenant on Economic, Social and Cultural Rights: a Perspective on its Development, Oxford University Press: Oxford.

Mashood A. Baderin and Robert McCorquodale, 2007, The International Covenant on Economic, Social and Cultural Rights: Forty Years of Development in Mashood A. Baderin and Robert McCorquodale (eds.), Economic, Social and Cultural in Action, Oxford University Press Inc., New York.

Nihal Jayawickrama, 2002, The Judicial Application of Human Rights Law, Cambridge University Press: Cambridge.

\section{Journal/Paper/Articles:}

Ida Elisabesth Koch, "Economic, Social and Cultural Rights as Components in Civil and Political Rights: a hermeneutic perspective", The International Journal of Human Rights, Vol. 10 No. 4, December 2006

Jackbeth K. Mapulanga-Hulston, "Examining the Justiciability of Economic, Social and Cultural Rights", The International Journal of Human Rights, Vol. 6 No. 4, Frank Cass Publishing, London, Winter 2002.

Jackie Dugard, Adjudicating of Socio-Economic Rights in South Africa: Progress Made and Challenges Remaining, Workshop Memperkuat Justisiabilitas HakHak Ekonomi, Sosial dan Budaya: Prospek dan Tantangan, Yogyakarta, 13-15 November 2007, PUSHAM UII and Norwegian Centre for Human Rights.

Okeowo Ademola Oladimeji, Economic, Social and Cultural Rights: Rights or Privileges? (December 12, 2008). Available at SSRN: http://ssrn.com/ abstract=1320204 or http://dx.doi.org/10.2139/ssrn.1320204

Suparman Marzuki, Upaya Litigasi dan Non Litigasi atas Pelanggaran Hak Ekosob di Indonesia, Workshop Memperkuat Justisiabilitas Hak-Hak Ekonomi, Sosial dan Budaya: Prospek dan Tantangan, Yogyakarta 13-15 November 2007.

Yuval Shany, "Stuck in a Moment in Time: The International Justiciability of Economic, Social and Cultural Rights", International Law Forum of the Hebrew University of Jerusalem Law Faculty, August 2006. Available at: www.ssrn. com/abtract $=920753$ 